\title{
BILATERAL OTITIS MEDIA AND UNILATERAL SENSORINEURAL HEARING LOSS AS THE FIRST SIGNS OF WEGENER'S GRANULOMATOSIS
}

\section{George S. Korres, Pavlos Maragkoudakis, Panagiotis Kousoulis, Thomas P. Nikolopoulos}

ENT Clinic, Attikon Hospital, University of Athens, Athens, Greece

Corresponding author: Dr George Korres, 10-12 Dorilaiou St., N. Erythraia, 14671, Athens, Greece, Phone: +30 6945 997916, e-mail: gfkorres@gmail.com

Abstract

Background: Wegener's granulomatosis (WG) is a rare disease characterised by blood vessel inflammation. Due to its endorgan damage it is life threatening, primarily affecting the upper and lower respiratory tract (nose, sinuses, trachea, lungs) and the kidneys.

Materials, Methods, Results: In this paper we describe the case of a 46-year-old woman who within one year developed bilateral otitis media and unilateral sensorineural hearing loss as the first clinical manifestations of Wegener's granulomatosis.

Conclusions: Even though bilateral otitis media is not a rare condition, in some cases it can be associated with a systemic disease. Suspicion of such a diagnosis should be reinforced when sensorineural hearing loss is present and the history of chronic otitis media is short. In the absence of other typical findings, the role of the otorhinolaryngologist is very important and any case with such symptoms should be thoroughly investigated.

Keywords: sensorineural hearing loss • bilateral otitis media • Wegener's granulomatosis

\section{OTITIS MEDIA BILATERAL E HIPOACUSIA PERCEPTIVA UNILATERAL COMO PRIMEROS SÍNTOMAS DE LA GRANULOMATOSIS DE WEGENER}

Resumen

Introducción: La granulomatosis de Wegener es una enfermedad poco frecuente que se caracteriza por la inflamación de los vasos sanguíneos. Se trata de una enfermedad potencialmente mortal para el enfermo, ya que daña los órganos, sobre todo las vías respiratorias altas y bajas (nariz, senos nasales, tráquea, pulmones) y los riñones.

Material, método, resultados: En el presente trabajo describimos el caso de una mujer de 46 años que desarrolló en un año otitis media bilateral e hipoacusia perceptiva unilateral como primeros síntomas clínicos de la granulomatosis de Wegener.

Conclusiones: A pesar de que la otitis media bilateral es una enfermedad común, en algunos casos puede estar relacionada con una enfermedad sistémica. La presencia de hipoacusia perceptiva y un corto historial de otitis media deberían fortalecer la sospecha de este diagnóstico. Si no aparecen otros síntomas típicos de la enfermedad, el otorrinolaringólogo jugará un papel importante y todos los casos en los que aparecen estos síntomas deberán ser examinados a conciencia.

Palabras clave: hipoacusia perceptiva • otitis media bilateral • granulomatosis de Wegener

\section{ДВУСТОРОННЕЕ ВОСПАЛЕНИЕ СРЕДНЕГО УХА И ОДНОСТОРОННЯЯ ПЕРЦЕПТИВНАЯ ТУГОУХОСТЬ КАК ПЕРВЫЕ СИМПТОМЫ ГРАНУЛЕМАТОЗА ВЕГЕНЕРА}

\section{Изложение}

Введение: Гранулематоз Вегенера - это редкая болезнь, которая характеризуется воспалением кровеносных сосудов. Эта болезнь угрожает жизни больного, так как она ведет к повреждению органов, прежде всего верхних и нижних дыхательных путей (носа, придаточных пазух, трахеи, легких) и почек. 
Материал, метод, результаты: В этой работе мы описываем случай 46-летней женщины, у которой на протяжении года развилось двустороннее воспаление среднего уха и односторонняя перцептивная тугоухость как первые клинические симптомы гранулематоза Вегенера.

Заключение: Несмотря на то, что двустороннее воспаление среднего уха не является редким заболеванием, в некоторых случаях оно может быть связано с заболеванием всего организма. Подозрение такого диагноза должно усилить наличие перцептивной тугоухости и краткая история воспаления среднего уха. При отсутствии других типичных симптомов заболевания отоларинголог должен сыграть важную роль и каждый случай, в котором имеются такие симптомы должен быть тщательно исследован.

Ключевые слова: перцептивная тугоухость • двустороннее воспаление среднего уха • гранулематоз Вегенера

\title{
OBUSTRONNE ZAPALENIE UCHA ŚRODKOWEGO I JEDNOSTRONNY NIEDOSŁUCH ODBIORCZY JAKO PIERWSZE OBJAWY ZIARNINIAKOWATOŚCI WEGENERA
}

\begin{abstract}
Streszczenie
Wprowadzenie: Ziarniniakowatość Wegenera jest rzadką chorobą charakteryzującą się zapaleniem naczyń krwionośnych. Jest to choroba zagrażająca życiu chorego gdyż prowadzi do uszkodzenia organów, przede wszystkim górnych i dolnych dróg oddechowych (nosa, zatok, tchawicy, płuc) i nerek.
\end{abstract}

Material, metoda, wyniki: W niniejszej pracy opisujemy przypadek 46-letniej kobiety, u której w przeciągu 1 roku rozwinęło się obustronne zapalenie ucha środkowego i jednostronny niedosłuch odbiorczy jako pierwsze kliniczne objawy ziarniniakowatości Wegenera.

Wnioski: Pomimo, że obustronne zapalenia ucha środkowego nie jest rzadką chorobą, w niektórych przypadkach może być powiązane z chorobą ogólnoustrojową. Podejrzenie takiej diagnozy powinna wzmocnić obecność niedosłuchu odbiorczego i krótka historia zapalenia ucha środkowego. Przy braku innych typowych objawów choroby otorynolaryngolog ma do odegrania ważną rolę i każdy przypadek, w którym występują takie objawy powinien zostać gruntownie przebadany.

Słowa kluczowe: niedosłuch odbiorczy • obustronne zapalenie ucha środkowego • ziarniniakowatość Wegenera

\section{Background}

Wegener's granulomatosis is a rare disease that affects 1 in 30,000 people, characterised by blood vessel inflammation (vasculitis). It is considered to be an aberrant hypersensitivity reaction to an unknown antigen, and is therefore a disease with no known cause. The granulomas that develop are a type of inflammatory tissue around the vessels. The disease is life-threatening, due to the end-organ damage which primarily affects the upper and lower respiratory tract (nose, sinuses, trachea, lungs) and the kidneys. In this paper we describe the case of a 45 -year old woman with bilateral otitis media and unilateral sensorineural hearing loss which were the first clinical manifestations of Wegener's granulomatosis.

\section{Materials, Methods, Results}

The patient first attended our clinic about two years ago complaining of symptoms of chronic otitis media of the left ear (purulent otorrhea and pain) and was treated conservatively with topical and oral antibiotics.

A year later, and while being abroad, the patient was hospitalised, complaining of persistent discharge from the left ear and otalgia. A CT scan of the head showed complete opacification of the left mastoid air cells, compatible with chronic mastoiditis. Minimal sphenoid disease with air - fluid level sign was also noted. Once again she was given appropriate conservative treatment for chronic otitis media. However, a hearing test performed at that time showed a profound sensorineural hearing loss on the same side. Three months later, she was readmitted to our hospital feeling severely ill and complaining again of earache and otorrhea, although the symptoms were right-sided this time. Vertigo, tinnitus, and facial paralysis were all absent on initial examination. Episcleritis of both eyes was noted. No nasal deformity, thyroid swelling, oral ulcers, or arthritis were seen. An audiogram showed a slight conductive hearing loss on the right side and a profound sensorineural hearing loss on the left.

Her CBC showed a white blood cell count of $20,600 / \mu \mathrm{L}$ with $91.4 \%$ neutrophil, an erythrocyte sedimentation rate of $92 \mathrm{~mm} / 1 \mathrm{hr}$ and c-reactive protein at 134. Red blood cell count, platelet count, and blood electrolytes were normal. During her stay at our clinic, aggravation of renal function was also observed, with serum creatinine levels rising up to 1.8. A renal ultrasound showed a cyst 1.7 $\mathrm{cm}$ in diameter on the left kidney, next to the renal pelvis. A chest CT scan showed nodules bilaterally, followed by a brain magnetic resonance imaging which described a subacute ischemic infarction on the left shell. The findings of a nasal biopsy were compatible with chronic rhinitis 


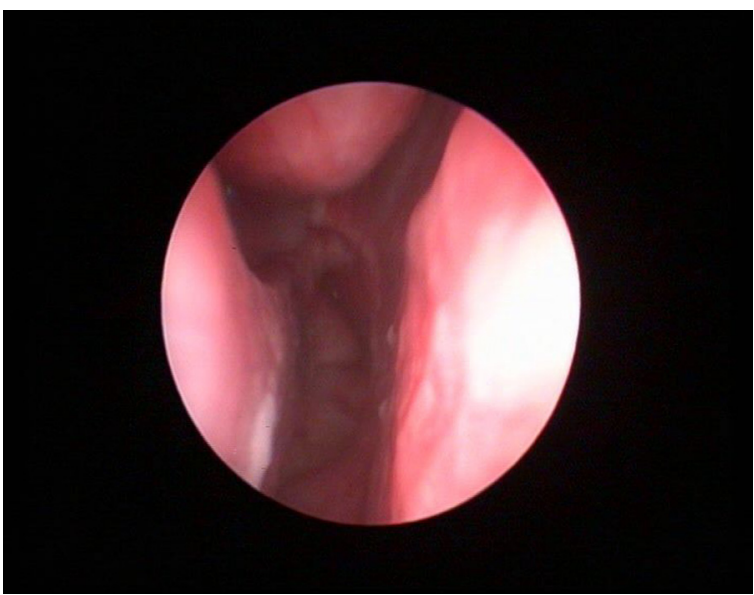

Figure 1. Endoscopy shows signs of chronic rhinitis.

(Figure 1). The head computed tomography (CT) scan had similar findings as the one performed abroad (Figure 2). No signs of granulomatous tissue, inflammation, or vasculitis were present. A biopsy was also taken from a nodule on the right leg which was histologically compatible with septal panniculitis. A Mantoux test (small amount of tuberculin injected under the skin) was negative. Serology tests for human immunodeficiency virus proved negative. Blood tests taken from the patient revealed positive c-ANCA (1:160), positive anti-PR3 $(300 \mathrm{U} / \mathrm{mL})$, and antinuclear antibodies (1:80). Therefore, Wegener's granulomatosis was diagnosed and the patient was treated with corticosteroids ( $1 \mathrm{mg} / \mathrm{kg} /$ day) and cyclophosphamide $(2 \mathrm{mg} / \mathrm{kg} /$ day $)$. Plasmapheresis was also performed due to an incident of intra-alveolar haemorrhage (the hematocrit had dropped from $30.7 \%$ to $21 \%$ and hemoglobin to $7.2 \mathrm{~g} / \mathrm{dL}$ ).

\section{Discussion}

In this case report, the patient developed bilateral otitis media along with unilateral sensorineural hearing loss (SNHL). These findings raised questions about whether these manifestations were part of a systemic disease. It is well known that SNHL might be present in chronic otitis media. The causative agents of acute and chronic otitis media (Str. pneumoniae and Str. pyogenes) produce molecularly related toxins (pneumolysin and streptolysin $\mathrm{O}$ ) that can form large pores in target membranes. The round window membrane permits toxic material to enter the inner ear and biochemically alter the inner ear fluids, resulting in gradual end-organ dysfunction [1].

However, this was not the most probable cause for the SNHL in the present case since the history of chronic otitis media was rather short.

Most of the patients suffering from Wegener's granulomatosis exhibit otologic symptoms. Otological involvement may be divided into: (1) serous otitis media, (2) chronic otitis media, (3) sensorineural hearing loss, (4) vertigo, and (5) facial nerve palsy [2]. The most common finding is chronic otitis media, while sensorineural hearing loss is less frequent and poorly understood [3]. Suggested mechanisms include vasculitis of the vasa vorum and cochlear vessels and granulomatous compression of the cochlea $[4,5]$.

The gold standard for diagnosis of Wegener's granulomatosis is the discovery of granulomatosis, necrosis, and vasculitis on pathological examination of biopsied tissue. In our patient, nasal involvement was absent based on clinical examination and so the biopsies taken from the nose where found negative for granulomas. C-ANCA (centrally accentuated antineutrophil cytoplasmic antibodies), discovered in 1985 by Van der Woude et al. [6], are circulating autoantibodies particularly associated with systemic vasculitis. In our case, the discovery of these autoantibodies suggested an autoimmune pathogenesis for Wegener's granulomatosis. Anti-PR3 is used for the quantitative determination of autoantibodies to proteinase 3 (PR3) in human serum for the differential diagnosis of autoimmune systemic vasculitis (SV), since they are described to be pathognomonic for Wegener's granulomatosis. It is one of four serine protease homologues [7] in the azurophilic granules of monocytes [8-10]. Several in vitro studies have provided evidence that PR3 may directly contribute to this vascular injury. It is of note that PR3 is over-expressed in a variety of acute and chronic myeloid leukemia cells [11] but this diagnosis was excluded according to other findings and investigations.

Immunosuppressive drugs are used for the treatment of Wegener's granulomatosis. Cyclophospamide, along with corticosteroids, have increased the median survival rate to 8.5 years; the 10 -year survival rate is estimated to be $40 \%$ if the kidney is involved and $60-70 \%$ if not; and 1 -year

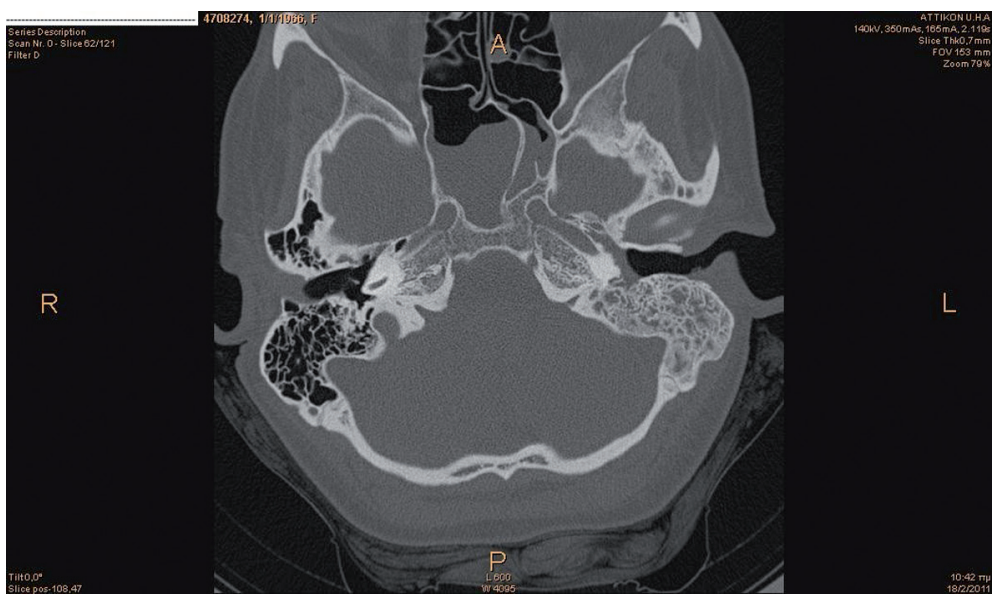

Figure 2. The head CT scan shows partial obliteration of the sphenoid sinuses and signs of chronic otitis media in the left ear. 
and 3-year actuarial survival rates are $80.5 \%$ and $60 \%$ respectively [12]. The main causes of death remain kidney failure and infection.

One month after receiving the appropriate treatment for both Wegener's granulomatosis and chronic otitis media, the hearing on the right side returned to normal. Clinical examination of both ears showed no pathological findings and the tympanic membranes were intact. However profound hearing loss was still present in the left ear.

In our patient the diagnosis was made using biochemical and serum tests along with the findings of the chest CT-scan, since the biopsy taken from the nasal mucosa showed no pathology. When facing bilateral symptoms of chronic otitis media, especially with a short history, the physician needs to have a high degree of suspicion in order to make an early diagnosis $[14,15]$ of Wegener's granulomatosis. In our case the ENT specialist played an important role in establishing a correct diagnosis.

\section{Conclusions}

Although bilateral chronic otitis media is not a rare condition, in some cases it can be associated with systemic disease. Suspicion of such a diagnosis is reinforced if SNHL is present. In the absence of other typical findings, the role of the otorhinolaryngologist can be very important and any case with such symptoms should be thoroughly investigated.

\section{References:}

1. Engel F, Blatz R, Kellner J, Palmer M, Weller U, Bhadki S. Breakdown of the round window membrane permeability barrier evoked by streptolysin O: possible etiologic role in development of sensorineural hearing loss in acute otitis media. Infect Immun, 1995; 63(4): 1305-10.

2. Takagi D, Nakamaru Y, Magachi S, Faruta Y, Fukuda S. Otologic manifestations of Wegener's granulomatosis. Laryngoscope, 2002; 112: 1684-90.

3. D'Cruz DP, Baguley E, Asherson RA, Hughes GR. Ear, nose,throat symptoms in subacute Wegener's granulomatosis. BMJ, 1989; 299: 419-22.

4. McCaffrey TV, McDonald TJ, Facer GW, DeRemee RA. Otologic manifestations of Wegener's granulomatosis. Otolaryngol Head Neck Surg, 1980; 88: 586-93.

5. Luqmani R, Jubb R, Emery P, Reid A, Adu D. Inner ear deafness in Wegener's granulomatosis. J Rheumatol, 1991; 18: 766-68.

6. Van der Woude FJ, Rasmussen N, Lobatto S et al. Autoantibodies against neutrophils and monocytes: Tool for diagnosis and marker of disease activity in Wegener's granulomatosis. Lancet, 1985; 1: 425-29.

7. Ohlsson K, Olsson I. The neutral proteases of human granulocytes.Isolation and partial characterization of granulocyte elastases. Eur J Biochem, 1974; 42: 519-27.

8. Rao NV, Wehner NG, Marshall BC, Gray WR, Gray BH, Hoidal JR. Characterization of proteinase-3 (PR-3), a neutrophil serine proteinase. Structural and functional properties. J Biol Chem, 1991; 266: 9540-48.
9. Dewald B, Rindler-Ludwig R, Bretz U, Baggiolini M. Subcellular localization and heterogeneity of neutral proteases in neutrophilic polymorphonuclear leukocytes. J Exp Med, 1975; 141: 709-23.

10. Gabay JE, Heiple JM, Cohn ZA, Nathan CF. Subcellular location and properties of bactericidal factors from human neutrophils. J Exp Med, 1976; 164: 1407-21.

11. Dengler R, Munstermann U, al Batran S, Hausner I, Faderl S, Nerl C, Emmerich B: Immunocytochemical and flow cytometric detection of proteinase 3 (myeloblastin) in normal and leukaemic myeloid cells. Br J Haematol, 1985; 89: 250-57.

12. Pinède L, Ninet J, Duhaut $P$, Coppère $B$, Demolombe-Rague S, Girard-Madoux MH, Pasquier J. [Wegener granulomatosis. Anatomoclinical study. Review of the literature]. Ann Med Interne (Paris), 1995; 146(5): 339-64. [in French]

13. Kloeck I, Crols R, De Belder T, Vandist V, Schmelzer B. Wegener's granulomatosis presenting as otomastoiditis. A case report. B-ENT, 2006; 2(1): 7-12.

14. Wierzbicka M, Puszczewicz M, Bartochowska A, Szyfter W. The otologic manifestation of Wegener's granulomatosis - review of contemporary achievements in diagnostics and treatment. Otolaryngol Pol, 2012; 66(4): 254-58.

15. Wierzbicka M, Szyfter W, Puszczewicz M, Borucki L, Bartochowska A. Otologic symptoms as initial manifestation of wegener granulomatosis: diagnostic dilemma. Otol Neurotol, 2011; 32(6): 996-1000. 